\title{
Renovação Editorial
}

\author{
Rubens Belfort Jr.
}

Com alegria e esperança vemos os Arquivos Brasileiros de Oftalmologia entrar em uma nova fase.

Desde 1938 Waldemar Belfort Mattos ao fundar os Arquivos Brasileiros de Oftalmologia preocupava-se com o grande número de publicações científicas brasileiras de efêmera existência e comprometeu-se, como editor do recém-fundado Arquivos Brasileiros de Oftalmologia a manter sua continuidade e publicação. Assim o fez até 1958 sendo sucedido por meu pai Rubens que transmitiu a mim esta responsabilidade. Assim, desde 1971, formado médico e ainda não oftalmologista passei a trabalhar e ajudar oficialmente nos Arquivos Brasileiros de Oftalmologia. Naturalmente pois, inúmeras vezes na infância e adolescência, assisti minha mãe e meu pai, juntos, corrigirem provas tipográficas dos Arquivos.

Mais que meu avô e meu pai foram meus pais, também minha mãe, que mantiveram os Arquivos Brasileiros de Oftalmologia, inclusive financeiramente. Completa-se agora a fase iniciada há vários anos atrás para permitir a transmissão serena da editoria científica dos Arquivos Brasileiros de Oftalmologia à nossa Oftalmologia como todo.

Estou feliz em ter conseguido manter meu compromisso de continuar na editoria científica dos Arquivos Brasileiros de Oftalmologia enquanto meu pai estivesse vivo e em transmitir essa editoria para a pessoa que meu pai também sempre julgou ter todas as condições para tal.

O Prof. Harley Bicas e o Conselho Editorial dos Arquivos Brasileiros de Oftalmologia (Mauro Campos, Cristina Muccioli, Mauro Goldchmit, Samir Bechara e Vital Paulino Costa) dispensam apresentação, constituem o exemplo do excelente nível e qualidade científica, ética e editorial da nossa especialidade e representam o futuro além de já terem um passado e uma atividade extremamente importante no presente.

Desde 1977 a parceria dos Arquivos Brasileiros de Oftal- mologia e Conselho Brasileiro de Oftalmologia se manteve e aumentou a qualidade editorial, a sua circulação e a abrangência. O carinho e o amor que minha família dedicou aos Arquivos Brasileiros de Oftalmologia é agora também repartido pelo Conselho Editorial e a grande família do Conselho Brasileiro de Oftalmologia e pela grande gestora e secretária D. Claudete Moral a quem minha família e eu somos e toda a Oftalmologia brasileira deve ser grata.

Teria mais motivos e razões (profissionais, afetivas etc.) para manter-me nessa posição de que para demitir-me mas é imprescindível que os Arquivos Brasileiros de Oftalmologia respirem agora um ar totalmente novo sob editoria científica madura, profissional e independente da minha.

Capacidade profissional (médica, oftalmológica e editorial), vontade (séria) e disponibilidade (inclusive de tempo), além de uma representatividade multi-institucional foram os critérios para escolha do presente Conselho Editorial.

Sabedor que nenhum de nós jamais vai conseguir realizar tudo que pretende e que é impossível tentar novas realizações e empreendimentos sem terminar anteriores, resolvi em setembro de 99, comunicar ao Prof. Harley Bicas, ao Conselho Editorial e ao Presidente do Conselho Brasileiro de Oftalmologia minha decisão. Decisão, sem falsa modéstia extremamente acertada. Saber sair e a hora de sair é mais importante do que tentar e conseguir o poder.

Para terminar quero agradecer carinhosamente a todos aqueles que nestes 29 anos colaboraram comigo na edição dos Arquivos Brasileiros de Oftalmologia, enviando artigos, revisando-os e realizando os sem números de tarefas solicitadas. Tenho certeza que todos eles juntamente comigo continuaremos a prestigiar os Arquivos Brasileiros de Oftalmologia e seu novo editor científico, Prof. Harley Bicas. 